ground water-tables. Many areas, including London, are over water-tables which are known to be dropping, but London depends only in part on its underground supplies. Overground supplies have been developed, because the rate of consumption from underground supplies has exceeded the available quantities of water. Sir William Pugh said that a deep borehole drilled at Burford by the Geological Survey entered Upper Coal Measures at about $1,100 \mathrm{ft}$., and they were proved to a thickness of $2,660 \mathrm{ft}$. It is not known whether they are underlain by productive Coal Measures because the borehole was stopped by technical difficulties at $3,767 \mathrm{ft}$. Within the comparatively small confines of the British Isles there is a remarkable range of phenomena of geological interest and of materials of economic importance.

\section{Florigenic Hormone in the Strawberry}

C. Sironval has given a comprehensive account of observations and experiments on the inception of flowering in an ever-flowering strain of strawberry, Fragaria vesca L. var. semperflorens Duch. (C.R. de Recherches, Trav. du Centre de Recherches des Hormones Végétales, No. 18, 9-229, Feb. 1957, Bruxelles). The author has found that during the course of development from the seed, the initial vegetative phase is followed by a second distinctive physiological phase, designated as the photophase. During this phase, the conditions essential for the onset of flowering are long days and a fluctuating daily temperature - warm days and cold nights. This period of development can be distinguished by characteristic features in leaf morphology and coloration. Once induced, the flowering phase persists until the death of the plant. The characteristic development of the photophase is immediately arrested by exposure to short days. Sironval's experimental observations indicate clearly that the photophase is the period when the specific transformations which prepare the way for flowering take place. In particular, he has directed attention to the fact that changes in the metabolism of the chlorophylls are especially distinctive during this phase. During exposure to long days he finds that there is a relative lowering of the amount of chlorophyll $b$. The accumulated evidence is held to be indicative of a correlation between the chlorophyll metabolism, environmental conditions - in particular, the daylength-and the inception of flowering. When a crude extract of the unsaponifiable fraction of leaves from flowering strawberry plants-and here particular interest may attach to vitamin $\mathrm{E}$ (in low concentrations) and a sterol (in high concentrations)-was applied to the meristems of plants not yet in the flowering phase, cell division was activated in the axial region of the meristem, this being characteristic of the transition to the flowering state.

\section{Australian Biochemical Society}

The Australian Biochemical Society was founded at the time of the meeting of the Australian and New Zealand Association for the Advancement of Science in Melbourne in August 1955. At that meeting Dr. M. R. Lemberg was elected as the first president, and a constitution was adopted. The first annual conference was held in Sydney in May 1956 and the second annual conference was held in Melbourne during June 5-7. At this latter meeting fiftyseven papers were presented, and abstracts of these papers will be published in the Australian Journal of Science. The present president is Prof. V. M. Trikojus, Department of Biochemistry, University of Melbourne, and the hon. secretary is Dr. F. D. Collins, Department of Biochemistry, Australian National University.

\section{Announcements}

Dr. A. Vedel TANING, director of the Danish Fisheries and Oceanographic Research Institute, has been elected an honorary member of the Marine Biological Association of the United Kingdom.

THE following have recently been elected to office in the Institution of Electrical Engineers for the session 1957-58: President, T. E. Goldup; Vice. Presidents, S. E. Goodall, Dr. Willis Jackson, G. S. C. Lucas, Sir Hamish D. Maclaren, C. T. Melling; Honorary Treasurer, Viscount Falmouth.

THE recently published Yearbook of Forest Pro. ducts Statistics, 1956 (pp. vi +170 . Rome : Food and Agriculture Organization of the United Nations ; London: H.M. Stationery Office, 1956. 12s. 6d.; 2.50 dollars), is the tenth issue of this report, covering details of world forestry output, trade and consumption compiled from information supplied by more than 120 countries throughout the world.

A "Joining of Metals" conference on "The Wetting and Spreading of Liquid Metals on Solid Metal Surfaces", organized by the Department of Industrial Metallurgy in the University of Birmingham, is to be held at the University of Birmingham on September 25. Further details and enrolment forms can be obtained from the Secretary to the Department.

A sERIES of eight lectures on operational research and cybernetics in industry has been arranged by the Department of Operational Research and Cybernetics of the United Steel Companies, Ltd., in co. operation with Dr. G. Lawton, principal of the Sheffield College of Commerce and 'Iechnology, to be presented during October and November on Wednesdays from 2.30 to 4 p.m. The course is addressed to senior management, and is likely to be followed in 1958 by a longer and more detailed course addressed to practitioners who may be appointed to carry out this type of work. The course will be introduced by R. S. Gander, development manager in the Department of Operational Research and Cybernetics, and the later lectures, also delivered by members of the Department, will be on "Queues", by K. D. Tocher, research manager; "Operational Research Models", by R. S. Gander; "Operational Research Machines", by D. G. Owen, computer applications manager; "Processes involving Chance", by K. D. Tocher ; "Information", by P. G. Lucas, operations manager ; "Production Control" and "Cybernetics", by Stafford Beer, head of the Depart. ment. Further details can be obtained from the College of Technology, Sheffield, 1, or the Department of Operational Research and Cyberneties of the United Steel Companies, Ltd.

ADDEndum. The symposium on "Microchemistry", to be held at the University of Birmingham under the auspices of the Society for Analytical Chemistry, and announced in Nature of June $29(179,1337 ; 1957)$, will take place during August 20-27, 1958. 